\title{
REAL CONVERGENCE TRENDS IN CENTRAL AND EASTERN EUROPEAN COUNTRIES TOWARDS EUROZONE: TIME-VARYING CORRELATION APROACH
}

\author{
Petr Rozmahel
}

\section{Keywords:}

business cycle, convergence, correlation, Eurozone, optimum currency areas

\section{Klíčová slova:}

hospodářský cyklus, konvergence, korelace, Eurozóna, optimální měnová oblast

\begin{abstract}
The paper deals with an actual issue of the Euro adoption in the Central and Eastern European countries. The main goal is to assess the preparedness of candidate European countries to adopt the Euro from a perspective of the theory of Optimum Currency Areas (OCA). The measure of dynamic similarity of business cycles of selected Central and Eastern European countries (CEE), Baltic countries and the Eurozone was applied in the analysis. This measure indicates dynamic convergence trends of the CEE and Baltics towards the Eurozone. Business cycle correlation belongs to characteristics listed within a frame of the New Theory of Optimum Currency Areas approach. Particularly, the rolling window correlation of Gross Domestic Product and Industrial Production time series were applied to asses the dynamic moments in the evolution of similarity in business cycles of the analysed European candidate countries and the Eurozone. The results shed some light on continuing convergence process in Baltic, CEE countries and Eurozone. A possible impact of a beginning of the global financial crisis on the business cycle correlation results are also discussed in the text.
\end{abstract}

\begin{abstract}
Abstrakt
Článek se věnuje problematice přijetí eura $\mathrm{v}$ zemích střední a východní Evropy. Hlavním cílem je posoudit připravenost kandidátských evropských zemí přijmout euro z pohledu teorie optimálních měnových oblastí (OCA). Kritérium dynamické korelace hospodářských cyklů vybraných zemí střední a východní Evropy, baltských zemí a eurozóny bylo aplikováno v analýze. Toto kritérium umožňuje odhalit dynamické konvergenční trendy v analyzovaných zemích vzhledem $\mathrm{k}$ eurozóně. Sladěnost hospodářských cyklů patří $\mathrm{k}$ charakteristikám definovaným v rámci tzv. Nové teorie optimálních měnových oblastí. Dynamická sladěnost byla měřena pomocí klouzavé korelace ukazatelů hrubého domácího produktu a průmyslové produkce. Klouzavá korelace umožňuje popsat dynamiku vývoje podobnosti hospodářských cyklů zkoumaných ekonomik $\mathrm{k}$ měnové unii. Z výsledků vyplývá pokračující konvergenční proces zemí střední a východní Evropy a pobaltských republik k eurozóně. V textu je také diskutován možný vliv začínající globální ekonomické krize na výsledky korelace hospodářských cyklů.
\end{abstract}




\section{Introduction}

In the Czech Republic and other candidate countries form Central and Eastern Europe the discussion on the timing of the Euro adoption got intensified after Slovakia successfully joined the Eurozone in 2009. Apart from the traditional Maastricht criteria evaluation the National banks, governments and other institutions in the Central and Easter European countries (CEE) use other supplementary tests to indicate a preparedness of countries to join the Eurozone. Various measures of business cycles similarity and other criteria listed in the frame of the Optimum Currency Areas theory (OCA) have become very popular to apply in the analytical studies. The OCA theory in the traditional papers starting from Mundell's pioneering article (Mundell, 1961) including Kenen (1963), Ingram (1962) or McKinnon (1969) sets the criteria defining the optimum currency area. Fulfilling of the OCA criteria minimise a risk of asymmetric shocks and increase the probability of an appropriate functioning of a common monetary policy within a currency union. Later the list of OCA criteria was enhanced with e.g. business cycle similarity or asymmetry of demand and supply shocks (see Mongelli, 2002 or Tavlas 1993) in accordance with New OCA theory.

The paper focuses on measuring of the business cycles similarity between CEE economies and the Eurozone. The measure of rolling window correlation was applied to indicate the dynamic evolution of the similarity in business cycles and to see the convergence or divergence trends. The results should help to answer the question how the CEE countries converge to the Eurozone and what is the actual level of business cycle similarity. Comparable correlation coefficients to the Eurozone member countries should indicate an appropriate level of preparedness of countries to join the Eurozone from this selective OCA perspective.

The analysis uses the indicators of Gross Domestic Product (GDP) and Industrial Production (IP) to approximate business cycles. The Eurostat and IMF were the main sources of the data. The Hodrick-Prescott Filter and First Order Logarithm Differencing technique (FOD) were used to stylise the data and to indicate the classical and growth cycles in a sense of definitions of Burns-Mitchel (1961) and Lucas (1977) respectively. The rolling window correlation analysis was used to measure the dynamic correlation of the stylised time series of GDP and IP approximating the business cycles. The resultant time varying correlation coefficients show the changing trends in business cycle similarity over time. In case of GDP cycles the rolling windows cover 5 years of quarterly data. In case of IP cycles three years of monthly data make the rolling parts of the time series. The GDP time series covered the quarterly data of 1996-2008 (Greece 2000-2008, Ireland 1997-2008) and IP the monthly data of 1993-2008 (Greece 1995-2008, Euro-area 1998-2008). Eurostat was the source of GDP data. International Financial Statistics (IFS) of the International Monetary Fund (IMF) provided the data on IP. The Baltic countries Estonia, Latvia and Lithuania were also included in the GDP cycles analysis. Germany and Euro-area average were the reference benchmark in the analysis.

The paper is structured as follows. After the introduction explaining the motivation of the paper, methodology and data used, the analytical parts follow. The first analytical part includes descriptive statistics of analysed time series and results of business cycles correlations. Rolling window correlation was used in the second chapter to indicate the convergence trends of business cycle similarity in analysed countries. Third part includes a short note on approach to regional GDP measuring in the Czech Republic. Fourth section concludes the analysis. 


\section{Descriptive statistics}

The input data of descriptive statistics comprises the first log difference of seasonally adjusted quarterly GDP (Table 1) and monthly IP (Table 2). Descriptive statistics allow measuring the average quarterly growth rate (in percentage), standard deviation indicating volatility of the cycles, minimum and maximum rate. The normalised deviation denotes the relative volatility comparing to the Euro-area average.

Table 1: Descriptive statistics of GDP growth in Eurozone members, CEE and Baltic countries

\begin{tabular}{|l|cccccc|}
\hline & Mean & Median & St.deviation & Norm.st.dev. & Min & Max \\
\hline AT & 0.0059 & 0.0066 & 0.0033 & 0.5823 & -0.0019 & 0.0114 \\
GER & 0.0035 & 0.0035 & 0.0067 & 1.1752 & -0.0213 & 0.0159 \\
EUR & 0.0054 & 0.0051 & 0.0057 & 1.0000 & -0.0161 & 0.0284 \\
FRA & 0.0050 & 0.0053 & 0.0044 & 0.7796 & -0.0112 & 0.0126 \\
ESP & 0.0084 & 0.0090 & 0.0041 & 0.7150 & -0.0098 & 0.0153 \\
POR & 0.0048 & 0.0042 & 0.0076 & 1.3260 & -0.0159 & 0.0210 \\
IRL & 0.0133 & 0.0127 & 0.0233 & 4.0910 & -0.0741 & 0.0722 \\
GRE & 0.0096 & 0.0093 & 0.0041 & 0.7177 & 0.0006 & 0.0183 \\
\hline CR & 0.0075 & 0.0095 & 0.0074 & 1.2904 & -0.0109 & 0.0214 \\
HU & 0.0087 & 0.0102 & 0.0053 & 0.9372 & -0.0118 & 0.0158 \\
POL & 0.0108 & 0.0121 & 0.0115 & 2.0105 & -0.0324 & 0.0598 \\
SLO & 0.0098 & 0.0097 & 0.0105 & 1.8457 & -0.0419 & 0.0390 \\
SVK & 0.0125 & 0.0129 & 0.0162 & 2.8428 & -0.0341 & 0.0674 \\
\hline EE & 0.0147 & 0.0184 & 0.0166 & 2.9196 & -0.0442 & 0.0505 \\
LT & 0.0147 & 0.0173 & 0.0125 & 2.1979 & -0.0229 & 0.0390 \\
LV & 0.0140 & 0.0191 & 0.0217 & 3.8058 & -0.0524 & 0.0617 \\
\hline
\end{tabular}

Source: Eurostat, author's calculations

Note: First log differences of seasonally adjusted quarterly GDP in 1996-2008. Two members of CEE-5 (SLO, SVK) already adopted the Euro.

Note: AT - Austria, GER - Germany, EUR - Eurozone, FRA - France, ESP - Spain, POR - Portugal, IRL Ireland, GRE - Greece, CR - Czech Republic, HU - Hungary, POL - Poland, SLO - Slovenia, SVK - Slovakia, EE - Estonia, LT - Lithuania, LV - Latvia.

Table 2: Descriptive statistics of IP growth in the Eurozone members and CEECs

\begin{tabular}{|l|cccccc|}
\hline & Mean & Median & St.deviation & Norm.st.dev. & Min & Max \\
\hline AT & 0.0034 & 0.0020 & 0.0197 & 2.1809 & -0.0485 & 0.0653 \\
GER & 0.0012 & 0.0022 & 0.0133 & 1.4711 & -0.0458 & 0.0420 \\
EUR & 0.0007 & 0.0021 & 0.0090 & 1.0000 & -0.0368 & 0.0199 \\
FRA & 0.0005 & 0.0010 & 0.0111 & 1.2363 & -0.0357 & 0.0381 \\
IT & 0.0002 & 0.0000 & 0.0113 & 1.2567 & -0.0398 & 0.0302 \\
ESP & 0.0009 & 0.0009 & 0.0174 & 1.9278 & -0.0801 & 0.0693 \\
POR & 0.0010 & 0.0008 & 0.0304 & 3.3776 & -0.0969 & 0.1051 \\
GRE & 0.0008 & 0.0014 & 0.0244 & 2.7031 & -0.0788 & 0.0773 \\
IRL & 0.0067 & 0.0039 & 0.0515 & 5.7134 & -0.2069 & 0.1364 \\
\hline CR & 0.0022 & 0.0045 & 0.0264 & 2.9332 & -0.0799 & 0.0677 \\
HU & 0.0051 & 0.0065 & 0.0257 & 2.8512 & -0.1504 & 0.0681 \\
POL & 0.0057 & 0.0072 & 0.0387 & 4.2938 & -0.1309 & 0.1168 \\
SVK & 0.0028 & 0.0083 & 0.0370 & 4.1039 & -0.1571 & 0.1116 \\
SLO & 0.0009 & 0.0026 & 0.0252 & 2.7999 & -0.1583 & 0.0574 \\
\hline
\end{tabular}

Source: IFS IMF, author's calculations

Note: First log differences of seasonally adjusted monthly IP in 1993-2008. 
Comparing to the $0,5 \%$ average quarterly growth rate of the Eurozone average $(0,35$ in Germany), the CEE as well as Baltic countries could be considered as converging economies. Also dynamically growing Ireland and Greece show significant real convergence to the average. Normalised standard deviation depicts Hungary as the less volatile CEE economy closely to the Eurozone cycle volatility. Also growing Ireland reveals high GDP growth volatility.

The industrial production is used as an appropriate complementary aggregate economic activity indicator reflecting actual use of production factors highly correlated with GDP series. In addition, the IP index is available in monthly frequencies revealing higher relative volatility. The IP statistics offer a similar picture to GDP. All CEE countries apart from Slovenia reveal faster monthly growth in IP comparing to $0,07 \%$ in case of Euro-area average and $0,12 \%$ monthly growth rate in Germany. Poland, Slovakia and Ireland again reveal high cycles' volatility.

\section{Real Convergence Measuring - Rolling Window Correlation of Business Cycles}

A rolling window correlation describes a short or middle-term dynamics of the business cycle convergence. It identifies the short term trends of the convergence or divergence during the whole analysed period. The time-varying coefficients measure a correlation of moving periods rolling during the whole time periods. The analysis includes five-year rolling window correlation of GDP cycles and three-year rolling window correlation of IP cycles. Thus a concrete coefficient refers to a correlation of previous five- or three-year sample.

Figure 1 shows clear convergence tendencies of all selected Eurozone member countries during the whole analysed period, though the FOD cycles reveal relatively lower levels of short term correlations (except form last few years). FOD cycles also give some evidence of some diverging trends of Ireland, Spain and Portugal (the EU-periphery countries) until 20067. The actual levels of convergence are very high close to range $0,8-1$.

Figure 1: Five-year rolling windows correlations of GDP cycles of the Eurozone member countries towards the Euro-area average

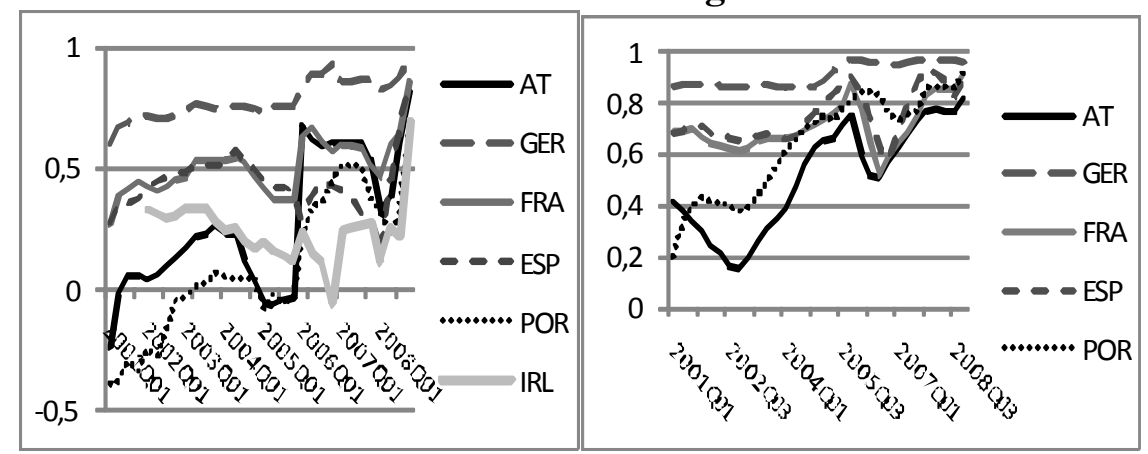

Source: Eurostat, author's calculations 
Figure 2: Five-year rolling windows correlations of GDP cycles of the CEECs towards the Euro-area average

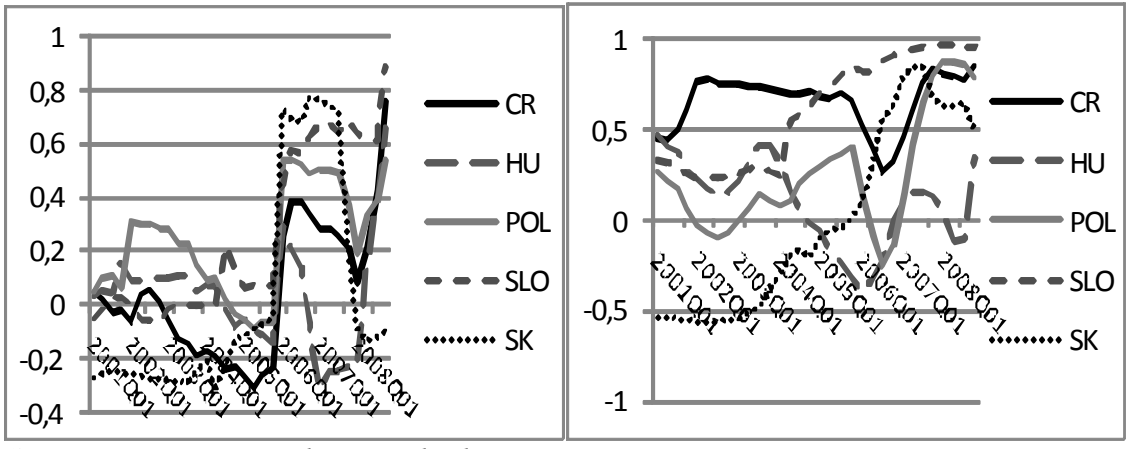

Source: Eurostat, author's calculations

Figure 3: Five-year rolling window correlations of GDP cycles of the Baltic countries towards the Euro-area average

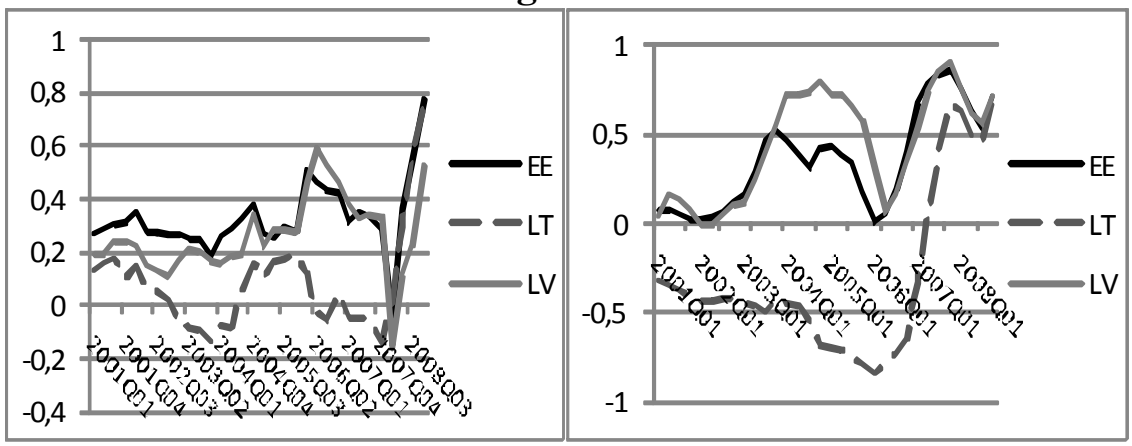

Source: Eurostat, author's calculations

Note: The figures 1-3 depict the five-year rolling window correlation of the input data-logs of adjusted quarterly GDP stylized with the first order differencing technique (FOD) in the left part and the HodrickPrescott filter $(H P, \lambda=1600)$ in the right part.

The short-term convergence tendencies are not in case of CEE countries as clear as in the Eurozone countries. Apart from last 3 years the converging as well as diverging trends are changing. The influence of FOD and HP filters is obvious. First order differencing technique produces lower correlations similarly to previous two correlation techniques (actual crosscorrelation and correlation in two consecutive periods). FOD cycles in all CEE countries also reveal long periods of diverging trends. The levels of correlation at the beginning of the period are also very high in the similar range as in the Eurozone countries. The Baltic countries converge at the end of analysed period. The lowest levels of convergence show Lithuania that was diverging to the Eurozone in most of the analysed period. A rapid increase in correlation in the end of analysed period in all countries possibly reflects negative GDP performance of the overall economies. The crises moved all developed economies in the phase of recession which increased the business cycles similarity. That conclusion could be also proven when looking at three-year rolling window correlation of the IP cycles. All analysed countries even the Eurozone members went through the phases of short-term convergence and divergence. Portugal cycle was diverging most of the time. Also IP cycles of CEE countries changed the recession and contraction phases. All countries converged significantly to the end of the period. In a sense of the OCA theory the world economic crises is a kind of a symmetric shock. This situation paradoxically increases a business cycles correlation and predicates a better preparedness of the candidate countries to join the Eurozone. The IP cycles analysis also indicates a potential influence of detrending. The FOD cycles show lower time-varying coefficients comparing to HP cycles. 
Figure 4: Three-year rolling window correlations of IP cycles of the Eurozone member countries towards Germany

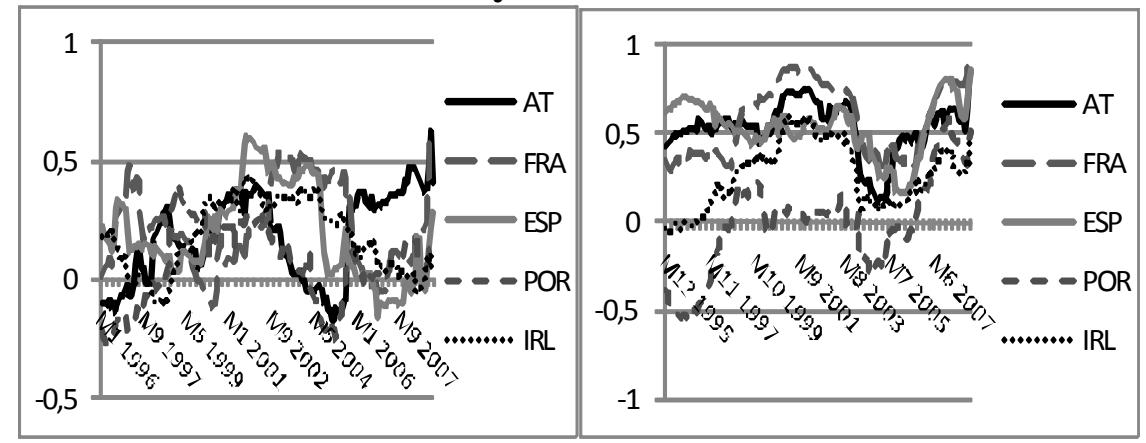

Source: Eurostat, author's calculations

Figure 5: Three-year rolling windows correlations of IP cycles of the CEECs towards Germany

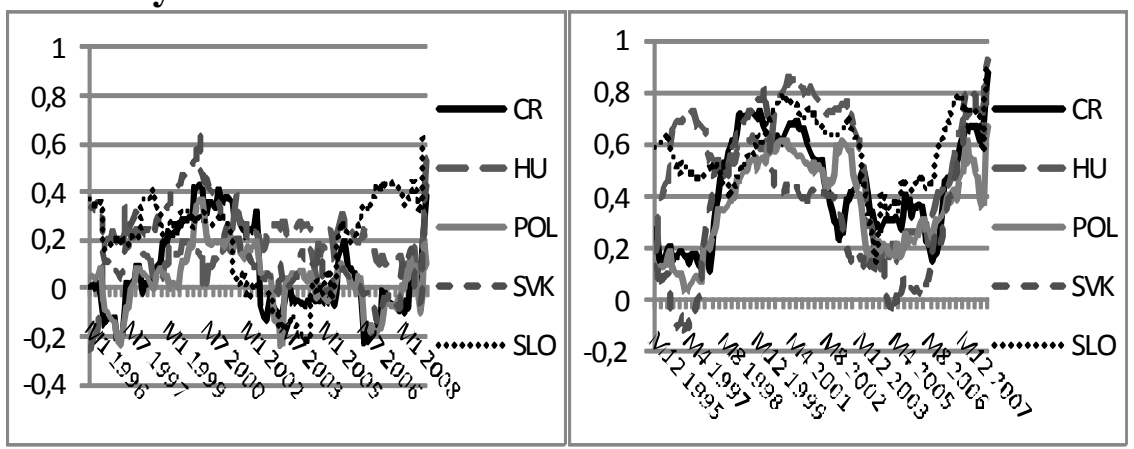

Source: Eurostat, author's calculations

Note: The figures 4,5 depict the three-year rolling window correlation of the input data-logs of adjusted quarterly GDP stylized with the first order differencing technique (FOD) in the left part and the Hodrick-

Prescott filter $(H P, \lambda=14400)$ in the right part..

\section{A note on a regional approach to measure the GDP: the case of the Czech Republic}

Integration and globalisation processes imply reducing the meaning of national economic borders and stresses the significance of regions. A possible impact of economic and monetary integration upon selected regions in the monetary union provided Krugman (1993) in his early work on the European monetary integration. He points out a problem of possible regional concentration and specialisation of production due to economic integration in Europe. This opinion was an opposite argument to the European commission presented in the well-known study One Market-One Money (1990).

Considering measuring the convergence and actual similarity of the business cycles in selected regions in Europe, one must identify the regional business cycles. To identify such cycles the regional GDP statistics is a necessary source for the analysis. The Case of the Czech Republic provides an interesting example how the methodological aspects can complicate the convergence analysis ${ }^{1}$.

The method "top-down" of measuring regional GDP based on counting the gross value added in individual regions (starting at the national level and coming down to the regional one) was

\footnotetext{
${ }^{1}$ An overall analysis of current problems and perspectives of regional GDP measuring see Nováková-Kouba (2008).
} 
accepted by Eurostat in 1997. Despite a numeric consistency of the national and regional accounts, the method remained criticised because it provided inaccurate results. The gross value added was allocated for the official firm domicile (usually in big cities). Thus the subsidiaries in a smaller cities and regions were allocated no value added (contribution to GDP). Accordingly, the "top-down" method overvalues the contribution to GDP by the big cities and small regions' production is undervalued ${ }^{2}$. In 2000 the new regional classification was established in the Czech Republic. The new regional levels NUTS 2 (Nomenclature Units Territorial Statistics) were constituted. The existing Czech counties at the NUTS 3 level were considered too small for the Eurostat statistics. Since 2000 the Czech Statistical Office has begun to count over the regional GDP for the newly established regions at NUTS 2 level.

The critique of the "top-down" method resulted in a change of the regional GDP measuring and the method of "pseudo-bottom-up" was implemented. This method include the combination of "top-down method" is still used for the financial and public sectors due to a difficult allocation of gross value added contribution by the subsidiaries. The "bottom-up" method is applied in case of productive and manufacturing units. The Czech Statistical Office is able to receive partial information from the manufacturing firms (and their regional subsidiaries) and aggregate them. However, such approach is timely consuming and still suffers with a certain inconsistency with the national accounts. The perspective of regional statistics in the Czech Republic is to use the "bottom-up" method in the financial as well as in non-financial sector as the method is considered the most accurate way of counting the regional GDP.

Accordingly, the methodological change in the regional GDP measuring during the transformation period (in 2004) decrease the reliability of data, short time series in an annual frequency available reduce an ability to analyse the business cycles similarity among the regions. Also an analysis of the contribution of the regional production cycles to the national GDP cycle is rather limited.

\section{Conclusion}

The resultant time-varying coefficients show higher similarity of the Eurozone member countries and Germany and Eurozone average. The CEE countries reveal somehow lower correlation with converging trends over time. The candidate countries and Baltic countries converge with GDP cycles towards the Eurozone. The IP cycles do not indicate clear convergence trends possibly due to their higher volatility. All countries converge significantly to the end of the analysed period. Particularly it is significant in case of GDP cycles. This fact might be the influence of the world economic crisis, which drives the business cycles of all developed countries into the recession phase. Whereas the Eurozone countries reveal stable or rising short term correlation, the CEE and Baltic countries went through phases of short term convergence and divergence (measured on five-year GDP and three-year IP rolling windows) during the whole time period. For all countries the time varying correlation increased rapidly at the end of analysed time period. The same effect of world economic crises upon the business cycles of the candidate and Eurozone countries raises short term actual similarity and paradoxically contributes to identification of better preparedness of countries to adopt Euro.

\footnotetext{
${ }^{2}$ It results in an extremely high value added measured in Prague and the lowest value of GDP contribution in Prague surroundings - the Central-Bohemia region.
} 
Regional approach to business cycle measuring seems to be difficult under condition of Czech statistics. The time series available do not provide long time series enough to receive robust results of regional business cycle similarity. However, it will likely be the trend of analysing disparities, similarities and convergence in Europe, where national borders lose economic sense slowly

Evaluating the results, it is quite difficult to asses definitely the preparedness of the CEE candidate countries to adopt the Euro according to rolling window correlation. The measure indicates the short term and middle term dynamics in convergence and divergence trends in correlation of the analysed business cycles. Although the convergence tendencies dominate at the end of analysed time periods, a possible influence of different detrending techniques and questionable impact of world economic crises might significantly influence the resultant timevarying coefficients.

\section{References}

[1] BURNS, A. F. and W. C. MITCHEL. 1946. Measuring Business Cycles. Vol. 2 of studies in Business cycles. NBER, New York.

[2] INGRAM, J. C. 1962. Regional Payments Mechanisms: The Case of Puerto Rico. University of North Carolina Press.

[3] KENEN, P. 1969. The Theory of Optimum Currency Areas: An Eclectic View. In: MUNDEL, R., SWOBODA, A. (eds.). Monetary Problems in International Economy. Chicago: University of Chicago Press.

[4] KRUGMAN, P. 1993. Lessons of Massachusetts for EMU. In Torres, F., Giavazzi, F. (eds.): Adjustment and Growth in the European Monetary Union. Cambridge: Cambridge Univerzity Press and CEPR, p. 241-261.

[5] LUCAS, R.E. 1977. Understanding Business Cycles. In Brunner, K. and A. H. and A. Swoboda, eds. Monetary Problems in International Economy. University of Chicago Press.

[6] MCKINNON, R. 1963. The Theory of Optimum Currency Area. American Economic Review, 4, 717 - 729.

[7] MONGELLI, P. F. 2002. New Views on The Optimum Currency Area Theory: What is EMU Telling Us? Working Paper ECB, 138.

[8] MUNDELL, R. A. 1961. A theory of Optimum Currency Areas. The American Economic Review, 51, 4, 657-665.

[9] NOVÁKOVÁ, M., KOUBA, L. 2008. The progress of the regional GDP in the regions of the Czech Republic with regard to the methogological aspects. Acta univ.agric.et silvic.Mendel.Brun., LVI, No. 6, pp.77-92.

[10] One Market, One Money. An Evaluation of the Potential Benefits and Costs of Forming an Economic and Monetary Union. European Commission. European Economy, Oct. 1990, no. 44, ISSN 0379-0991

[11] TAVLAS, G. S. 1993, The „New“ Theory of Optimum Currency Areas. The World Economy, no. 4, p. 663-685.

\section{Acknowledgements}

Results published in the paper are a part of a research project "Assessment of the Convergence Process in the Czech Republic and Selected Candidate Countries towards the Eurozone" No. 402/08/P494 supported by the Czech Science Foundation. 


\section{Classification JEL: E32, F41}

\section{Ing. Petr, Rozmahel, Ph.D.}

Výzkumné centrum

Provozně ekonomická fakulta

Mendelova univerzita v Brně

61300 Brno

petr.rozmahel@mendelu.cz 